\title{
Prognostic impact of interleukin-6 and C-reactive protein on patients with breast cancer
}

\author{
TATSUO SHIMURA ${ }^{1}$, MASAHIKO SHIBATA $^{2}$, KENJI GONDA $^{3}$, YUKO MURAKAMI ${ }^{4}$, \\ MASARU NODA ${ }^{4}$, KAZUNOSHIN TACHIBANA ${ }^{4}$, NORIKO ABE ${ }^{4}$ and TOHRU OHTAKE ${ }^{4}$ \\ Departments of ${ }^{1}$ Progressive DOHaD Research and ${ }^{2}$ Advanced Cancer Immunotherapy; ${ }^{3}$ Clinical Oncology Center; \\ ${ }^{4}$ Department of Breast Surgery, Fukushima Medical University, Fukushima 960-1295, Japan
}

Received October 23, 2018; Accepted February 27, 2019

DOI: $10.3892 / \mathrm{ol} .2019 .10183$

\begin{abstract}
The prognostic impacts of preoperative C-reactive protein (CRP) and interleukin (IL)-6 expression levels in patients with breast cancer remain controversial. A total of 55 female patients with invasive breast cancer were enrolled, and preoperative prognostic parameters including IL-6 and CRP were analyzed. Overall survival (OS) and recurrence-free survival (RFS) were estimated using the Kaplan-Meier method, and candidates' prognostic factors were examined using a Cox proportional hazard model. Using receiver operating characteristic curve analysis, IL- 6 at $10.0 \mathrm{pg} / \mathrm{ml}$ and CRP at $0.12 \mathrm{mg} / \mathrm{dl}$ were determined as threshold values to predict OS and RFS, respectively. Patients with IL- $6 \geq 10.0 \mathrm{pg} / \mathrm{ml}$ had poorer OS compared with those with IL- $6<10.0 \mathrm{pg} / \mathrm{ml}$ ( $\mathrm{P}=0.003$ ), and patients with $\mathrm{CRP} \geq 0.12 \mathrm{mg} / \mathrm{dl}$ had poorer RFS compared with those with CRP $<0.12 \mathrm{mg} / \mathrm{dl}(\mathrm{P}<0.001)$. Serum IL-6 level (hazard ratio, 13.230; 95\% confidence interval, 1.285-136.214; $\mathrm{P}=0.030$ ) and triple-negative subtype (hazard ratio, 11.739; 95\% confidence interval, 1.415-97.362; $\mathrm{P}=0.023)$ were independent prognostic factors for OS, and CRP expression level was an independent prognostic factor for RFS in patients with breast cancer (hazard ratio, 18.571; 95\% confidence interval, 2.240-153.949; $\mathrm{P}=0.007)$. In patients with invasive breast cancer, preoperative serum IL-6 and
\end{abstract}

Correspondence to: Professor Tatsuo Shimura, Department of Progressive DOHaD Research, Fukushima Medical University, 1 Hikarigaoka, Fukushima 960-1295, Japan

E-mail: tshimura@fmu.ac.jp

Abbreviations: ER, estrogen receptor; PgR, progesterone receptor; HER2, the human epidermal receptor 2; IL, interleukin; CRP, C-reactive protein; VEGF, vascular endothelial growth factor; G-CSF, granulocyte colony-stimulating factor; sICAM, soluble intercellular adhesion molecule; BMI, body mass index; RBP, retinol binding protein; TTR, transthyretin; TF, transferrin; NLR, neutrophil-to-lymphocyte ratio; LMR, lymphocyte-to-monocyte ratio; PBMCs, Peripheral blood mononuclear cells; ROC, receiver operating characteristic; OS, overall survival; RFS, recurrence-free survival

Key words: IL-6, CRP, OS, RFS, breast cancer triple-negative subtype may be independent prognostic factors for OS, while for RFS, preoperative CRP may be a more accurate prognostic factor compared with those currently established.

\section{Introduction}

Breast cancer is the most frequently occurring type of cancer with 1.7 million cases worldwide. In 2012 it was the leading cause of cancer-associated mortality, accounting for 521,900 cases in females (1). The identification of biomarkers for breast cancer, including estrogen receptor (ER), progesterone receptor (PgR) and the human epidermal receptor 2 (HER2), has enabled the prediction of patient prognosis and the establishment of novel therapeutic agents (2). Notably, clinicopathological surrogate definitions for molecular subtypes of breast cancer, including luminal A-like, luminal B-like with HER2 negative, luminal B-like with HER2 positive, HER2 positive with ER and PgR negative, and triple-negative have been used for treatment recommendations (3). However, other studies have reported controversial results for the use of molecular subtyping in the prediction of recurrence $(4,5)$.

One of the hallmarks of cancer is angiogenesis in conjunction with systemic and local inflammation (6). Crosstalk between angiogenesis and inflammatory signaling pathways may also contribute to cancer progression. Interleukin (IL)-6 and $\mathrm{C}$-reactive protein (CRP) are principal mediators and indicators of the inflammatory response. CRP, which was named for its capacity to precipitate C-polysaccharide of Streptococcus pneumoniae, is a sensitive and widely used inflammatory marker produced primarily in the liver, in response to IL-1, IL-6, tumor necrosis factor- $\alpha$ and IL-17 $(7,8)$. CRP was reported to be associated with poor prognosis in nasopharyngeal (9), hepatocellular (10), pancreatic (11), colorectal (12), renal (13), urothelial (14) and prostate cancer (15), in addition to breast cancer $(16,17)$. However, the association between CRP and the prognosis of patients with breast cancer remains controversial (18-20). The association between serum IL-6 expression levels and breast cancer has been reported in treatment prognosis (21-23) and resistance to chemotherapy (24), and other studies have reported an association between serum IL-6, CRP and breast cancer $(25,26)$. Although previous studies (21-23) have investigated the 
association between IL-6 and prognosis in patients with metastasis, the prognostic impact of preoperative IL-6 levels remains to be elucidated.

Galectin-3, a $\beta$-galactoside binding lectin is one of the most highly investigated key factors promoting angiogenesis and inflammation in breast cancer (27-29). Galectin-3 has been reported to induce the secretion of angiogenic factors from blood vascular endothelial cells in vitro, including as IL-6, vascular endothelial growth factor (VEGF), granulocyte colony-stimulating factor (G-CSF), granulocyte macrophage colony-stimulating factor and soluble intercellular adhesion molecule (sICAM)-1 (30). However, the association between circulating galectin-3 levels and the prognosis of breast cancer has yet to be clarified. The present study aimed to evaluate the prognostic impact of preoperative CRP and IL-6 expression levels in patients with breast cancer, in conjunction with angiogenic, inflammatory, immunological and nutritional parameters.

\section{Materials and methods}

Patients. Sera from 64 female preoperative patients with invasive breast cancer were collected between March 2011 and May 2013 at the Department of Breast Surgery, Fukushima Medical University Hospital (Fukushima, Japan), prior to starting treatment. Among these patients, 55 underwent curative-intent surgery (either modified radical mastectomy or partial mastectomy followed by irradiation); the remaining 9 patients had distant metastasis, and were therefore excluded. Thus, 55 preoperative patients with breast cancer (median age, 52; range, 37-83 years) were ultimately enrolled in the present study. Of the 55 patients, 17 were preoperatively diagnosed as having T4 tumor $(n=6)$ and/or axillary lymph node metastasis $(n=22)$, and subsequently received neoadjuvant chemotherapy using fluorouracil, epirubicin and cyclophosphamide. Following surgery, cancer stage was determined pathologically according to the Tumor-Node-Metastasis (TNM) classification system of malignant tumors, published in the Union for International Cancer Control, 8th edition (31). A total of 29 patients received adjuvant chemotherapy, including docetaxel, paclitaxel or capecitabine, and subsequent treatment with neoadjuvant chemotherapy $(n=17)$ due to a postoperative diagnosis of metastasis to the axillary lymph nodes $(\mathrm{n}=20)$, and/or having a triple-negative $(n=8)$ or HER2 $(n=4)$ subtype. Patient characteristics are summarized in Table I. The study protocol was approved by the Ethics Committee of Fukushima Medical University (approval no. 1095) and written informed consent was obtained from the enrolled patients.

Measurement of parameters. Using an ELISA (R\&D Systems, Inc., Minneapolis, MN, USA) according to the manufacturer's protocol, patient sera were evaluated to determine the concentrations of galectin-3 (cat. no. DGAL30), IL-6 (cat. no. D6050), VEGF (cat. no. DVE00), sICAM-1 (cat. no. DCD540) and G-CSF (cat. no. DCS50). The nutritional status of each patient was using a combination of the body mass index (BMI) and serum concentrations of total protein, albumin, retinol binding protein (RBP), transthyretin (TTR) and transferrin $(\mathrm{TF})$. These parameters were assessed at the Central Clinical Laboratory of Fukushima Medical
Table I. Patient characteristics.

\begin{tabular}{|c|c|c|}
\hline Category & Patients, n (total 55) & $\%$ \\
\hline \multicolumn{3}{|l|}{ Pathological T factor } \\
\hline $1 \mathrm{a}$ & 0 & 0.0 \\
\hline $1 \mathrm{~b}$ & 1 & 1.8 \\
\hline $1 \mathrm{c}$ & 21 & 38.2 \\
\hline 2 & 25 & 45.5 \\
\hline 3 & 2 & 3.6 \\
\hline $4 a$ & 0 & 0.0 \\
\hline $4 b$ & 6 & 10.9 \\
\hline \multicolumn{3}{|l|}{ Pathological $\mathrm{N}$ factor } \\
\hline 0 & 35 & 63.6 \\
\hline $1 \mathrm{a}$ & 13 & 23.6 \\
\hline $1 b$ & 0 & 0.0 \\
\hline $1 \mathrm{c}$ & 0 & 0.0 \\
\hline $2 \mathrm{a}$ & 6 & 11.0 \\
\hline $2 \mathrm{~b}$ & 0 & 0.0 \\
\hline $3 a$ & 0 & 0.0 \\
\hline $3 b$ & 1 & 1.8 \\
\hline $3 c$ & 0 & 0.0 \\
\hline \multicolumn{3}{|c|}{ Tumor-Node-Metastasis stage } \\
\hline IA & 17 & 31.0 \\
\hline IB & 0 & 0.0 \\
\hline IIA & 18 & 32.7 \\
\hline IIB & 7 & 12.7 \\
\hline IIIA & 7 & 12.7 \\
\hline IIIB & 5 & 9.1 \\
\hline IIIC & 1 & 1.8 \\
\hline \multicolumn{3}{|l|}{ Pathological subtype } \\
\hline Papillo-tubular & 18 & 32.7 \\
\hline Solid-tubular & 9 & 16.4 \\
\hline Scirrhous & 25 & 45.4 \\
\hline Other & 3 & 5.5 \\
\hline \multicolumn{3}{|l|}{ Histological grade } \\
\hline 1 & 24 & 43.6 \\
\hline 2 & 17 & 30.9 \\
\hline 3 & 11 & 20.0 \\
\hline Not graded & 3 & 5.5 \\
\hline \multicolumn{3}{|l|}{ Molecular subtype } \\
\hline Luminal A-like & 19 & 34.5 \\
\hline Luminal B/HER- & 9 & 16.4 \\
\hline Luminal B/HER+ & 15 & 27.3 \\
\hline HER2 & 4 & 7.3 \\
\hline Triple-negative & 8 & 14.5 \\
\hline \multicolumn{3}{|l|}{ Surgical procedure } \\
\hline $\mathrm{Bp}+\mathrm{SN}$ & 19 & 34.5 \\
\hline $\mathrm{Bp}+\mathrm{AX}$ & 8 & 14.5 \\
\hline $\mathrm{Bt}+\mathrm{SN}$ & 11 & 20.0 \\
\hline $\mathrm{Bt}+\mathrm{AX}$ & 17 & 31.0 \\
\hline
\end{tabular}

Luminal B/HER-, Luminal B-like human epidermal receptor 2 negative; Luminal B/HER+, Luminal B-like human epidermal receptor 2 positive; $\mathrm{Bp}+\mathrm{SN}$, partial mastectomy with sentinel node biopsy; $\mathrm{Bp}+\mathrm{AX}$, partial mastectomy with axillary lymph node dissection; $\mathrm{Bt}+\mathrm{SN}$, modified radical mastectomy with sentinel node biopsy; Bt+AX, modified radical mastectomy with axillary lymph node dissection. 

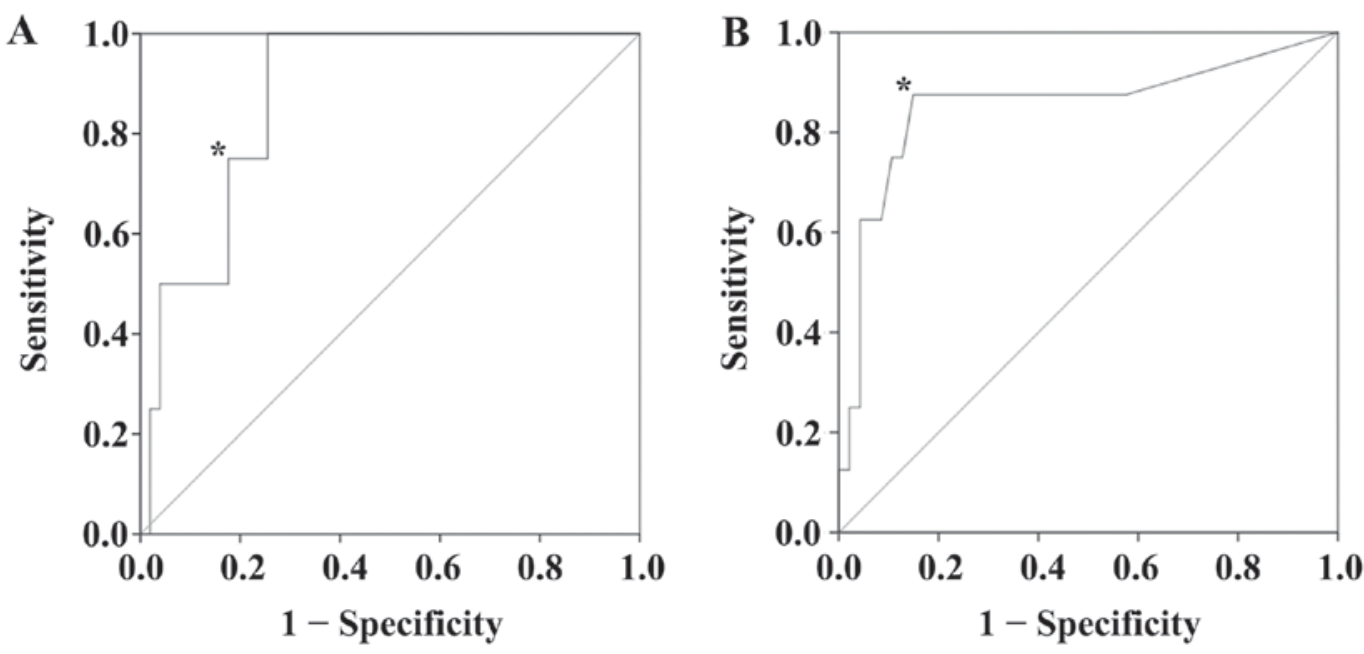

Figure 1. Receiver operating characteristic curve analysis. (A) The expression level of serum interleukin- 6 was determined to be a biomarker for predicting the overall survival of patients with breast cancer $(\mathrm{P}=0.013)$. The AUC was 0.877 , and $10.0 \mathrm{pg} / \mathrm{ml}$ was set as the cutoff value* $(\mathrm{sensitivity}=0.750$, and specificity $=0.824)$. (B) The CRP expression level was evaluated as a biomarker to predict RFS ( $\mathrm{P}=0.001)$. The AUC was 0.854 , and a level of $0.12 \mathrm{mg} / \mathrm{dl}$ was determined as the cutoff threshold* (sensitivity $=0.875$ and specificity $=0.851$ ). AUC, area under the curve; CRP, C-reactive protein; RFS, recurrence-free survival.

University Hospital. Indicators of inflammation, including CRP, white blood cell count, neutrophil, lymphocyte and monocyte counts, in addition to the neutrophil-to-lymphocyte ratio (NLR) and lymphocyte-to-monocyte ratio (LMR), were also verified.

The expression levels of the immunological cytokines IL-10, -12 and -17 were obtained. Peripheral blood mononuclear cells (PBMCs) were isolated using Ficoll-Hypaque columns (Pharmacia-Biotech, Uppsala, Sweden), and washed twice with RPMI-1640 medium (Wako Pure Chemical Industries, Ltd., Osaka, Japan). Isolated PBMCs were incubated at a concentration of $1 \times 10^{6}$ cells $/ \mathrm{ml}$ in $1 \mathrm{ml}$ RPMI-1640 (10\% heat-inactivated fetal calf serum; Gibco; Thermo Fisher Scientific, Inc., Waltham, MA, USA) for $24 \mathrm{~h}$ at $37^{\circ} \mathrm{C}$ and $5 \% \mathrm{CO}_{2}$, with the following stimuli: i) $20 \mu \mathrm{g} / \mathrm{ml}$ phytohemagglutinin for the IL-10 and IL-17 production assays; and ii) $0.01 \%$ Staphylococcus aureus Cowan strain 1 for the IL-12 assays. The supernatant was aliquoted and stored at $-80^{\circ} \mathrm{C}$ until use. Supernatant samples were subsequently thawed and used to determine the concentrations of IL-10, IL-12, and IL-17 using an ELISA. Following thawing, samples were used only once, and not all blood samples were of sufficient volume for all measurements.

Statistical analysis. All statistical calculations were performed using SPSS ${ }^{\circledR}$ v.24 (IBM Corp., Armonk, NY, USA). Data are presented as frequencies or percentages for categorical variables, and means \pm standard deviation for continuous variables, unless otherwise indicated. For categorical clinical variables, the differences between two groups were evaluated using the $\chi^{2}$ or the Fisher's exact test. The differences between continuous data were analyzed using the Mann-Whitney U test.

With regard to survival analysis, the mean observation period was 69.6 months (range, 55.3-81.4). The final assessment of disease status was made on December 12, 2017. Receiver operating characteristic (ROC) analysis was used to evaluate the prognostic value of the selected parameters.
Overall survival (OS) and recurrence-free survival (RFS) rates were determined using the Kaplan-Meier method, and the differences between the groups were assessed using the log-rank test. Prognostic factor candidates were subjected to univariate and multivariate analysis using a Cox proportional hazard model to identify independent predictors of prognosis; when $\mathrm{P}<0.1$ for univariate analysis, the candidate was also analyzed using multivariate analysis. $\mathrm{P}<0.05$ was considered to indicate a statistically significant difference.

\section{Results}

ROC curve analysis. Using ROC curve analysis, the serum expression level of IL-6 was determined to be a biomarker for the prediction of $\mathrm{OS}(\mathrm{P}=0.013)$, with a cutoff value of $10.0 \mathrm{pg} / \mathrm{ml}$ (Fig. 1A), a sensitivity of 0.750 and a specificity of 0.824. Additionally, the serum expression level of CRP was evaluated as a biomarker to predict RFS ( $\mathrm{P}=0.001)$, with a cutoff threshold of $0.12 \mathrm{mg} / \mathrm{dl}$ (Fig. 1B). At this cutoff value, the sensitivity was 0.875 and the specificity was 0.851 .

Associations between serum expression levels of IL-6 and CRP, and patient characteristics. Table II displays patient characteristics according to serum IL-6 or CRP levels. There were no statistically significant differences in pathological $\mathrm{T}$ factor, pathological $\mathrm{N}$ factor, TNM stage, administration of neoadjuvant or adjuvant chemotherapy, ER, PgR, or HER2 expression levels, lymphatic invasion or microscopic vascular invasion associated with IL-6 and CRP expression levels between groups.

Serum VEGF levels in patients with CRP $\geq 0.12 \mathrm{mg} / \mathrm{dl}$ (median, $472.0 \mathrm{ng} / \mathrm{ml}$; range, $170.0-1,100.0 \mathrm{ng} / \mathrm{ml}$ ) were significantly higher compared with those in patients with CRP $<0.12 \mathrm{mg} / \mathrm{dl}$ (median, $220.0 \mathrm{ng} / \mathrm{ml}$; range, $74.0-1,460.7 \mathrm{ng} / \mathrm{ml}$ ) $(\mathrm{P}=0.011)$. The Ki-67 labeling index of patients with CRP $\geq 0.12 \mathrm{mg} / \mathrm{dl}$ (median, 35.3\%; range, 3.1-80.0\%) was significantly higher compared with that in patients with CRP $<0.12 \mathrm{mg} / \mathrm{dl}$ (median, $16.4 \%$; range, $1.0-78.2 \%)(\mathrm{P}=0.035)$. The 
Table II. Patient characteristics according to IL-6 and CRP expression levels.

\begin{tabular}{|c|c|c|c|c|c|c|}
\hline Category & $\begin{array}{c}\mathrm{IL}-6<10.0 \mathrm{pg} / \mathrm{ml} \\
\mathrm{N}=43\end{array}$ & $\begin{array}{c}\mathrm{IL}-6 \geq 10.0 \mathrm{pg} / \mathrm{ml} \\
\mathrm{N}=12\end{array}$ & P-value & $\begin{array}{c}\mathrm{CRP}<0.12 \mathrm{pg} / \mathrm{dl} \\
\mathrm{N}=41\end{array}$ & $\begin{array}{c}\mathrm{CRP} \geq 0.12 \mathrm{pg} / \mathrm{dl} \\
\mathrm{N}=14\end{array}$ & P-value \\
\hline pT & & & 1.000 & & & 0.678 \\
\hline $1+2$ & 36 & 10 & & 35 & 11 & \\
\hline $3+4$ & 7 & 2 & & 6 & 3 & \\
\hline $\mathrm{pN}$ & & & 0.319 & & & 0.755 \\
\hline 0 & 29 & 6 & & 26 & 8 & \\
\hline$\geq 1$ & 14 & 6 & & 15 & 6 & \\
\hline Stage & & & 0.477 & & & 0.736 \\
\hline $\mathrm{I}+\mathrm{II}$ & 33 & 8 & & 31 & 10 & \\
\hline $\mathrm{III}+\mathrm{IV}$ & 10 & 4 & & 10 & 4 & \\
\hline Neoadjuvant chemotherapy & & & 0.735 & & & 0.742 \\
\hline- & 29 & 9 & & 29 & 9 & \\
\hline+ & 14 & 3 & & 12 & 5 & \\
\hline Adjuvant chemotherapy & & & 1.000 & & & 0.130 \\
\hline- & 20 & 6 & & 22 & 4 & \\
\hline+ & 23 & 6 & & 19 & 10 & \\
\hline Estrogen receptor & & & 0.689 & & & 0.477 \\
\hline- & 8 & 3 & & 8 & 4 & \\
\hline+ & 35 & 9 & & 33 & 10 & \\
\hline Progesterone receptor & & & 0.336 & & & 1.000 \\
\hline - & 18 & 3 & & 16 & 5 & \\
\hline+ & 25 & 9 & & 25 & 9 & \\
\hline Human epidermal receptor 2 & & & 0.183 & & & 1.000 \\
\hline - & 26 & 10 & & 27 & 9 & \\
\hline+ & 17 & 2 & & 14 & 5 & \\
\hline Lymphatic vessel invasion & & & 0.320 & & & 0.346 \\
\hline - & 24 & 4 & & 23 & 5 & \\
\hline+ & 19 & 7 & & 18 & 8 & \\
\hline Vascular invasion & & & 1.000 & & & 1.000 \\
\hline- & 27 & 7 & & 26 & 8 & \\
\hline+ & 16 & 4 & & 15 & 5 & \\
\hline
\end{tabular}

IL-6, interleukin-6; CRP, C-reactive protein. One patient with IL-6 $\geq 10.0 \mathrm{pg} / \mathrm{ml}$ and CRP $\geq 0.12 \mathrm{mg} / \mathrm{dl}$ was not included in the evaluation of lymphatic or vascular invasion.

BMI of patients with CRP $\geq 0.12 \mathrm{mg} / \mathrm{dl}$ (median, $24.2 \mathrm{~kg} / \mathrm{m}^{2}$; range, $16.4-29.6 \mathrm{~kg} / \mathrm{m}^{2}$ ) was significantly higher compared with that in patients with CRP $<0.12 \mathrm{mg} / \mathrm{dl}$ (median, $21.5 \mathrm{~kg} / \mathrm{m}^{2}$; range, $\left.20.8-40.3 \mathrm{~kg} / \mathrm{m}^{2}\right)(\mathrm{P}=0.001$; Fig. 2$)$. When patients were categorized according to IL-6 expression level (cutoff, $10.0 \mathrm{pg} / \mathrm{ml}$ ), there were no statistically significant differences among parameters. Serum expression levels of galectin-3, sICAM-1, RBP, TTR, TF, NLR and LMR, and the production of IL-12 and IL-17, were not significantly associated with the expression of IL-6 or CRP.

$O S$ and RFS. As revealed in Fig. $3 \mathrm{~A}$ and $\mathrm{B}$, patients with IL-6 $\geq 10.0 \mathrm{pg} / \mathrm{ml}$ possessed poorer OS and RFS compared with those with IL- $6<10.0 \mathrm{pg} / \mathrm{ml}(\mathrm{P}=0.010$ and $\mathrm{P}=0.038$, respectively). There were no statistically significant differences in OS between patients with different levels of CRP ( $\mathrm{P}=0.253$; Fig. 3C), whereas patients with CRP $\geq 0.12 \mathrm{mg} / \mathrm{dl}$ exhibited a poorer RFS compared with those with $\mathrm{CRP}<0.12 \mathrm{mg} / \mathrm{dl}$ ( $\mathrm{P}<0.001$; Fig. 3D). Differences in the serum expression levels of galectin-3, VEGF, sICAM-1 and G-CSF did not significantly affect the prognosis of patients with breast cancer.

Cox proportional hazards model. The following prognostic factors were analyzed using a Cox proportional hazards model: pathological $\mathrm{T}$ factor $(\mathrm{T} 1+\mathrm{T} 2$ vs. $\mathrm{T} 3+\mathrm{T} 4)$, pathological $\mathrm{N}$ factor (N0 vs. $\geq \mathrm{N} 1$ ), TNM stage (I +II vs. III + IV), triple-negative subtype (no vs. yes), CRP $(<0.12 \mathrm{mg} / \mathrm{dl}$ vs. $\geq 0.12 \mathrm{mg} / \mathrm{dl})$ and serum IL-6 expression level $(<10.0 \mathrm{pg} / \mathrm{ml}$ vs. $\geq 10.0 \mathrm{pg} / \mathrm{ml}$ ). Triple-negative subtype (hazard ratio, 8.795; $95 \%$ confidence interval, 1.230-62.875; $\mathrm{P}=0.030)$ and serum IL-6 expression level (hazard ratio, 10.785; 95\% confidence 

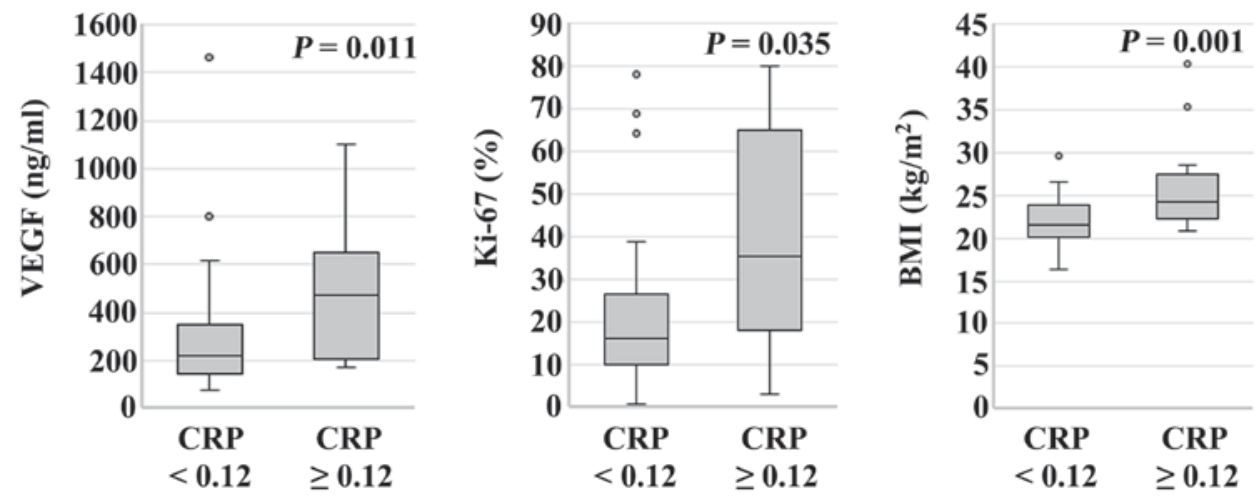

Figure 2. Association between CRP expression level and patient parameters. Serum VEGF levels in patients with CRP $\geq 0.12 \mathrm{mg} / \mathrm{dl}$ (median, $472.0 \mathrm{ng} / \mathrm{ml}$ range, $170.0-1,100.0 \mathrm{ng} / \mathrm{ml}$ ) were significantly higher compared with those in patients with $\mathrm{CRP}<0.12 \mathrm{mg} / \mathrm{dl}$ (median, $220.0 \mathrm{ng} / \mathrm{ml}$; range, $74.0-1,460.7 \mathrm{ng} / \mathrm{ml})$ $(\mathrm{P}=0.011)$. Ki-67 labeling index in patients with $\mathrm{CRP} \geq 0.12 \mathrm{mg} / \mathrm{dl}$ (median, 35.3\%; range, 3.1-80.0\%) was significantly higher compared with that of patients with CRP $<0.12 \mathrm{mg} / \mathrm{dl}$ (median, 16.4\%; range, 1.0-78.2\%) $(\mathrm{P}=0.035)$. BMI of patients with CRP $\geq 0.12 \mathrm{mg} / \mathrm{dl}\left(\mathrm{median}, 24.2 \mathrm{~kg} / \mathrm{m}^{2} ; \mathrm{range}, 16.4-29.6 \mathrm{~kg} / \mathrm{m}^{2}\right) \mathrm{was}$ significantly higher compared with that of patients with CRP $<0.12 \mathrm{mg} / \mathrm{dl}$ (median, $\left.21.5 \mathrm{~kg} / \mathrm{m}^{2} ; \mathrm{range}, 20.8-40.3 \mathrm{~kg} / \mathrm{m}^{2}\right)(\mathrm{P}=0.001)$. CRP, C-reactive protein; VEGF, vascular endothelial growth factor; BMI, body mass index.

A

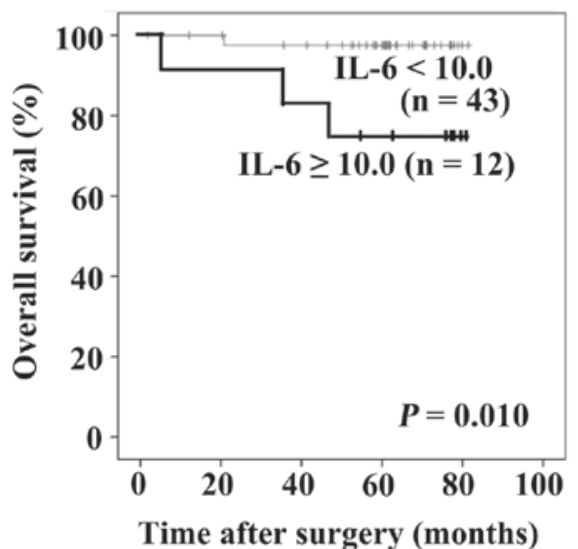

No. at risk

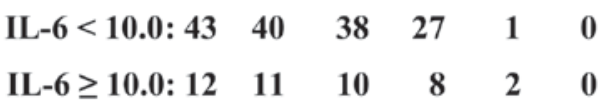

C

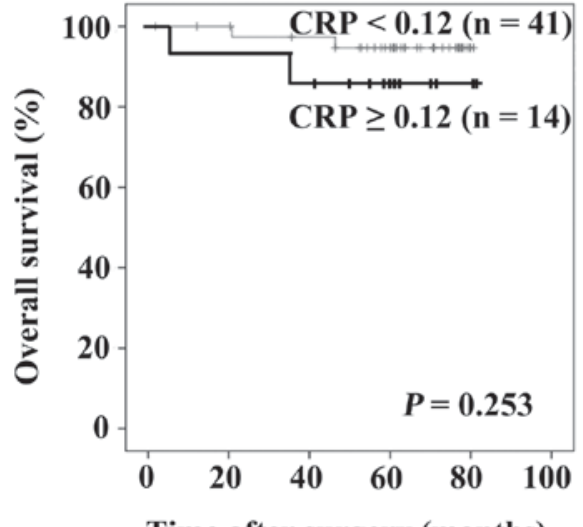

No. at risk

Time after surgery (months)
B

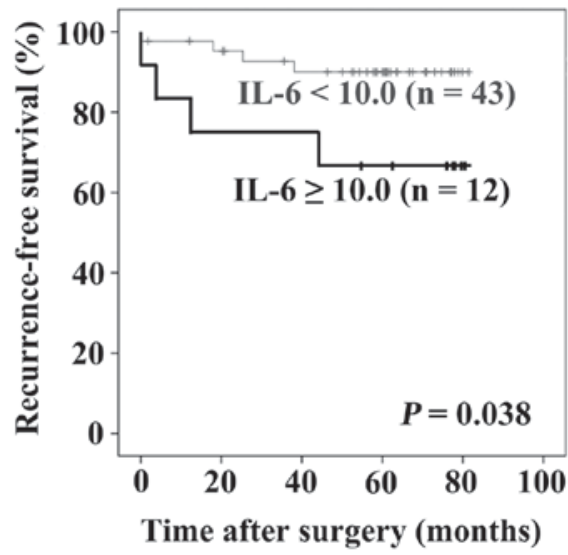

No. at risk

\begin{tabular}{|c|c|c|c|}
\hline$-6<10.0: 43$ & 38 & 34 & 24 \\
\hline$-6 \geq 10.0: 12$ & 9 & 9 & \\
\hline
\end{tabular}

D

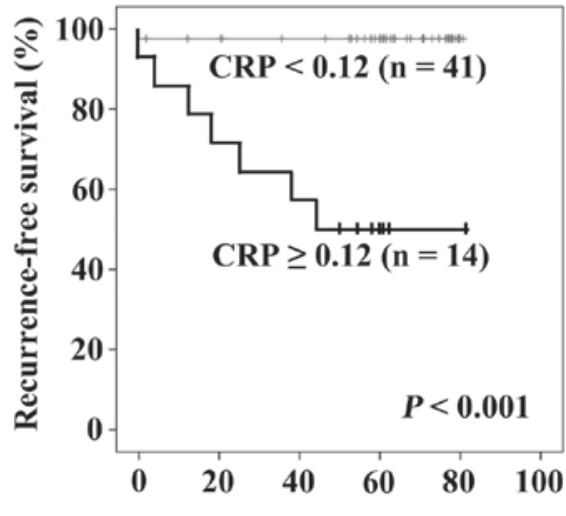

Time after surgery (months)

No. at risk

CRP < 0.12: $41 \quad 38 \quad 27 \quad 26 \quad 1 \quad 0$

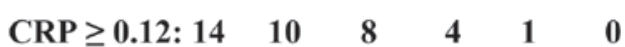

Figure 3. Patient survival calculated using the Kaplan-Meier method. (A) Patients with IL- $6 \geq 10.0 \mathrm{pg} / \mathrm{ml}$ exhibited poorer OS compared with those with IL-6 $<10.0 \mathrm{pg} / \mathrm{ml}(\mathrm{P}=0.010)$. (B) Patients with IL-6 $\geq 10.0 \mathrm{pg} / \mathrm{ml}$ exhibited poorer RFS compared with those with IL-6 $<10.0 \mathrm{pg} / \mathrm{ml}(\mathrm{P}=0.038)$. (C) There were no statistically significant differences in OS between patients with CRP $<0.12 \mathrm{mg} / \mathrm{dl}$ and with $\mathrm{CRP} \geq 0.12 \mathrm{mg} / \mathrm{dl}(\mathrm{P}=0.253)$. (D) Patients with CRP $\geq 0.12 \mathrm{mg} / \mathrm{dl}$ exhibited a poorer RFS compared with those with CRP $<0.12 \mathrm{mg} / \mathrm{dl}$ ( $\mathrm{P}<0.001)$. CRP, C-reactive protein; IL-6, interleukin-6; OS, overall survival; RFS, recurrence-free survival. 
Table III. Cox proportional hazards model.

A, Overall survival

\begin{tabular}{|c|c|c|c|c|c|c|}
\hline \multirow[b]{2}{*}{ Category } & \multicolumn{3}{|c|}{ Univariate analysis } & \multicolumn{3}{|c|}{ Multivariate analysis } \\
\hline & HR & $95 \% \mathrm{CI}$ & P-value & HR & $95 \% \mathrm{CI}$ & P-value \\
\hline $\mathrm{T}$ & 5.121 & $0.721-36.369$ & 0.102 & - & - & - \\
\hline $\mathrm{N}$ & 1.729 & $0.243-12.278$ & 0.584 & - & - & - \\
\hline TNM stage & 2.886 & $0.406-20.485$ & 0.289 & - & - & - \\
\hline $\mathrm{HG}$ & 7.198 & $0.652-79.503$ & 0.107 & - & - & - \\
\hline $\mathrm{TN}$ & 8.795 & $1.230-62.875$ & 0.030 & 11.739 & $1.415-97.362$ & 0.023 \\
\hline IL-6 & 10.785 & $1.122-103.693$ & 0.039 & 13.230 & $1.285-136.214$ & 0.030 \\
\hline CRP & 2.970 & $0.41-21.100$ & 0.277 & - & - & - \\
\hline
\end{tabular}

B, Recurrence-free survival

\begin{tabular}{lrrrrrr}
\hline & \multicolumn{3}{c}{ Univariate analysis } & & \multicolumn{2}{c}{ Multivariate analysis } \\
\cline { 2 - 5 } Category & HR & $95 \%$ CI & P-value & HR & $95 \%$ CI & P-value \\
\cline { 2 - 5 } T & 3.355 & $0.801-14.053$ & 0.098 & 2.499 & $0.583-10.711$ & 0.218 \\
N & 5.598 & $1.129-27.748$ & 0.035 & 3.429 & $0.677-17.364$ & 0.136 \\
TNM stage & 0.993 & $0.200-4.920$ & 0.993 & - & - & - \\
HG & 3.172 & $0.708-14.206$ & 0.131 & - & - \\
TN & 2.702 & $0.543-13.456$ & 0.225 & - & - \\
IL-6 & 3.637 & $0.733-18.040$ & 0.114 & & - \\
CRP & 23.865 & $2.930-194.408$ & 0.003 & & - & - \\
\hline
\end{tabular}

HR, hazard ratio; CI, confidence interval; T, pathological T factor; N, pathological N factor; TNM, Tumor-Node-Metastasis; HG, histological grade; TN, triple-negative molecular subtype; IL-6, interleukin-6; CRP, C-reactive protein.

interval, 1.122-103.693; $\mathrm{P}=0.039)$ were significantly associated following univariate analysis. Triple-negative subtype (hazard ratio, 11.739; 95\% confidence interval, 1.415-97.362; $\mathrm{P}=0.023$ ) and serum IL-6 expression level were independent prognostic factors for the OS of patients with breast cancer. With regard to RFS, the pathological $\mathrm{N}$ factor (hazard ratio, 5.598; 95\% confidence interval, 1.129-27.748; $\mathrm{P}=0.035)$ and CRP level (hazard ratio, 23.865; 95\% confidence interval, 2.930-194.408; $\mathrm{P}=0.003)$ showed statistical significance following univariate analysis, and the CRP expression level was an independent prognostic factor for RFS in patients with breast cancer (hazard ratio, 18.571; 95\% confidence interval, 2.240-153.949; $\mathrm{P}=0.007$; Table III).

\section{Discussion}

The prognostic impact of preoperative serum IL-6 expression level has been reported previously, but based only on the results of Kaplan-Meier analysis (26). Furthermore, the prognostic impact of serum IL-6 expression level has only been observed in patients with metastatic disease (21-23). Although the prognostic impact of preoperative CRP has been reported $(16,17)$, other studies have described controversial results $(18-20)$. Thus, the present study aimed to evaluate the prognostic impact of preoperative CRP and IL-6 expression levels in patients with breast cancer. It was revealed that preoperative expression levels of IL-6 and CRP effected OS and RFS, respectively.

IL-6 is secreted by various cell types, including breast cancer cells. The response to IL-6 in such cells depends on the expression of ERs (24). The ER-positive MCF-7 cell line does not secrete IL-6, whereas ER-negative MD-MBA-231 cells do (32,33). However, Fontanini et al (34) reported that expression levels of IL-6 correlated with ER expression. Ravishankaran and Karunanithi (25) reported that serum IL-6 expression levels correlated with the extent of tumor invasion, lymph node metastasis, distant metastasis and TNM staging. In the present study, IL-6 did not correlate with such tumor statuses.

In the present study, CRP expression level correlated with VEGF expression, Ki-67 labeling index and BMI. Expression levels of VEGF in breast cancer have been reported to correlate with poorer RFS (35). Although serum VEGF expression level was reportedly increased in patients with breast cancer, compared with healthy controls (36), numerous studies have suggested that it has no prognostic value (37,38). Highly proliferative tumors, including triple-negative breast cancer, show enhanced angiogenesis 
and reportedly exhibit high levels of VEGF expression (39). Additionally, the Ki-67 labeling index has been associated with OS in breast cancer (40). In the present study, serum expression levels of VEGF and the Ki-67 labeling index had no significant association with OS or RFS; however, a significant correlation with higher CRP expression indicates that they may contribute to poor RFS. Furthermore, increased risk of breast cancer was associated with increased body weight and obesity in women, particularly in postmenopausal patients, and a significant link was observed between CRP expression levels and BMI (41). The suggested association between elevated CRP expression level, VEGF, Ki-67 and BMI warrants further investigation.

Limitations of the present study include its relatively small patient cohort and short observational period. Also, lifestyle factors that may influence IL-6 and/or CRP expression levels, including smoking, menopausal status, and other comorbidities (including diabetes and cardiovascular disease), were not taken into account.

For ROC curve analysis, $10.0 \mathrm{pg} / \mathrm{m} \mathrm{IL-6} 1$ and $0.12 \mathrm{mg} / \mathrm{dl}$ CRP were determined as threshold values to predict OS and RFS, respectively. Patients with IL-6 $\geq 10.0 \mathrm{pg} / \mathrm{ml}$ exhibited poorer OS compared with those with IL-6 $<10.0 \mathrm{pg} / \mathrm{ml}$, and patients with $\mathrm{CRP} \geq 0.12 \mathrm{mg} / \mathrm{dl}$ exhibited poorer $\mathrm{RFS}$ compared with those with $\mathrm{CRP}<0.12 \mathrm{mg} / \mathrm{dl}$. In patients with breast cancer, serum IL- 6 and CRP expression levels were independent prognostic factors for OS and RFS, respectively. Specifically, CRP is indicated to be a superior prognostic marker compared with established prognostic factors, including $\mathrm{T}$ factor, $\mathrm{N}$ factor and histological grade, supporting a possible association between inflammation and recurrence in breast cancer.

In conclusion, in patients with invasive breast cancer, preoperative serum IL-6 expression levels and triple-negative subtype may be independent prognostic factors for OS, while for RFS, preoperative CRP expression level may be a more accurate prognostic factor compared with those already established. Particular attention should be paid to patients with higher preoperative IL-6 and/or CRP expression levels during preoperative follow-up for breast cancer.

\section{Acknowledgements}

Not applicable.

\section{Funding}

No funding was received.

\section{Availability of data and materials}

The datasets generated from the present study are available from the corresponding author upon reasonable request.

\section{Authors' contribution}

TS, MS and TO contributed to the conception, design, and integrity of this study. KG, YM, MN, KT and NA performed data acquisition, analysis, and interpretation. TS and MS drafted and critically revised the manuscript.

\section{Ethics approval and consent to participate}

The present study was approved by the Ethics Committee of Fukushima Medical University (approval no. 1095) and written informed consent was obtained from all enrolled patients. Additionally, all patient data were treated in accordance with the local privacy regulations.

\section{Patient consent for publication}

All patients provided written informed consent.

\section{Competing interests}

The authors declare that they have no competing interests.

\section{References}

1. Torre LA, Bray F, Siegel RL, Ferlay J, Lortet-Tieulent J and Jemal A: Global cancer statistics, 2012. CA Cancer J Clin 65: 87-108, 2015.

2. Kwa M, Makris A and Esteva FJ: Clinical utility of gene-expression signatures in early stage breast cancer. Nat Rev Clin Oncol 14: 595-610, 2017.

3. Goldhirsch A, Winer EP, Coates AS, Gelber RD, Piccart-Gebhart M, Thürlimann B, Senn HJ, Albain KS, André F, Bergh J, et al; Panel members: Personalizing the treatment of women with early breast cancer: Highlights of the St Gallen International Expert Consensus on the Primary Therapy of Early Breast Cancer 2013. Ann Oncol 24: 2206-2223, 2013.

4. Sanpaolo P, Barbieri V and Genovesi D: Prognostic value of breast cancer subtypes on breast cancer specific survival, distant metastases and local relapse rates in conservatively managed early stage breast cancer: A retrospective clinical study. Eur J Surg Oncol 37: 876-882, 2011.

5. Millar EK, Graham PH, O'Toole SA, McNeil CM, Browne L, Morey AL, Eggleton S, Beretov J, Theocharous C, Capp A, et al: Prediction of local recurrence, distant metastases, and death after breast-conserving therapy in early-stage invasive breast cancer using a five-biomarker panel. J Clin Oncol 27: 4701-4708, 2009.

6. Hanahan D and Weinberg RA: Hallmarks of cancer: The next generation. Cell 144: 646-674, 2011.

7. Tillett WS and Francis T: Serological reactions in pneumonia with a non-protein somatic fraction of pneumococcus. J Exp Med 52: 561-571, 1930.

8. Eklund CM: Proinflammatory cytokines in CRP baseline regulation. Adv Clin Chem 48: 111-136, 2009.

9. Fang Y, Xu C, Wu P, Zhang LH, Li DW, Sun JH, Li WF and Liao ZS: Prognostic role of C-reactive protein in patients with nasopharyngeal carcinoma: A meta-analysis and literature review. Medicine (Baltimore) 96: e8463, 2017.

10. Zheng Z, Zhou L, Gao S, Yang Z, Yao J and Zheng S: Prognostic role of C-reactive protein in hepatocellular carcinoma: A systematic review and meta-analysis. Int J Med Sci 10: 653-664, 2013.

11. Stevens L, Pathak S, Nunes QM, Pandanaboyana S, Macutkiewicz C, Smart N and Smith AM: Prognostic significance of pre-operative $\mathrm{C}$-reactive protein and the neutrophil-lymphocyte ratio in resectable pancreatic cancer: A systematic review. HPB (Oxford) 17: 285-291, 2015.

12. Woo HD, Kim K and Kim J: Association between preoperative C-reactive protein level and colorectal cancer survival: A meta-analysis. Cancer Causes Control 26: 1661-1670, 2015.

13. Hu Q, Gou Y, Sun C, Ding W, Xu K, Gu B, Xia G and Ding Q: The prognostic value of $\mathrm{C}$-reactive protein in renal cell carcinoma: A systematic review and meta-analysis. Urol Oncol 32: 50.e1-50.e8, 2014.

14. Luo Y, Fu SJ, She DL, Xiong HU and Yang LI: Preoperative C-reactive protein as a prognostic predictor for upper tract urothelial carcinoma: A systematic review and meta-analysis. Mol Clin Oncol 3: 924-928, 2015.

15. Liu ZQ, Chu L, Fang JM, Zhang X, Zhao HX, Chen YJ and $\mathrm{Xu} \mathrm{Q}$ : Prognostic role of C-reactive protein in prostate cancer: A systematic review and meta-analysis. Asian J Androl 16: 467-471, 2014. 
16. Allin KH, Nordestgaard BG, Flyger H and Bojesen SE: Elevated pre-treatment levels of plasma C-reactive protein are associated with poor prognosis after breast cancer: A cohort study. Breast Cancer Res 13: R55, 2011.

17. Sicking I, Edlund K, Wesbuer E, Weyer V, Battista MJ, Lebrecht A, Solbach C, Grinberg M, Lotz J, Hoffmann G, et al: Prognostic influence of pre-operative C-reactive protein in node-negative breast cancer patients. PLoS One 9: e111306, 2014

18. Frydenberg H, Thune I, Lofterød T, Mortensen ES, Eggen AE, Risberg T, Wist EA, Flote VG, Furberg AS, Wilsgaard T, et al: Pre-diagnostic high-sensitive C-reactive protein and breast cancer risk, recurrence, and survival. Breast Cancer Res Treat 155: 345-354, 2016.

19. Al Murri AM, Wilson C, Lannigan A, Doughty JC, Angerson WJ, McArdle CS and McMillan DC: Evaluation of the relationship between the systemic inflammatory response and cancer-specific survival in patients with primary operable breast cancer. Br J Cancer 96: 891-895, 2007.

20. Tibau A, Ennis M and Goodwin PJ: Post-surgical highly sensitive C-reactive protein and prognosis in early-stage breast cancer. Breast Cancer Res Treat 141: 485-493, 2013.

21. Salgado R, Junius S, Benoy I, Van Dam P, Vermeulen $P$, Van Marck E, Huget P and Dirix LY; Salgado R1: Junius S, Benoy I, Van Dam P, Vermeulen P, Van Marck E, Huget P and Dirix LY: Circulating interleukin-6 predicts survival in patients with metastatic breast cancer. Int J Cancer 103: 642-646, 2003.

22. Knüpfer H and Preiss R: Significance of interleukin-6 (IL-6) in breast cancer (Review). Breast Cancer Res Treat 102: 129-135, 2007.

23. Dethlefsen C, Højfeldt G and Hojman P: The role of intratumoral and systemic IL-6 in breast cancer. Breast Cancer Res Treat 138 : 657-664, 2013.

24. Al-Youzbaki WB, Al-Youzbaki NB and Telfah MM: Tissue polypeptide antigen \& interleukin-6: Are their serum levels a predictor for response to chemotherapy in breast cancer? Pak J Med Sci 30: 1108-1112, 2014.

25. Ravishankaran $\mathrm{P}$ and Karunanithi R: Clinical significance of preoperative serum interleukin-6 and C-reactive protein level in breast cancer patients. World J Surg Oncol 9: 18, 2011.

26. Babaei Z, Moslemi D, Parsian H, Khafri S, Pouramir M and Mosapour A: Relationship of obesity with serum concentrations of leptin, CRP and IL-6 in breast cancer survivors. J Egypt Natl Canc Inst 27: 223-229, 2015

27. Honjo Y, Nangia-Makker P, Inohara $\mathrm{H}$ and Raz A: Down-regulation of galectin-3 suppresses tumorigenicity of human breast carcinoma cells. Clin Cancer Res 7: 661-668, 2001.

28. Song YK, Billiar TR and Lee YJ: Role of galectin-3 in breast cancer metastasis: Involvement of nitric oxide. Am J Pathol 160: 1069-1075, 2002.

29. Nangia-Makker P, Wang Y, Raz T, Tait L, Balan V, Hogan V and Raz A: Cleavage of galectin-3 by matrix metalloproteases induces angiogenesis in breast cancer. Int J Cancer 127: 2530-2541, 2010.
30. Chen C, Duckworth CA, Zhao Q, Pritchard DM, Rhodes JM and Yu LG: Increased circulation of galectin-3 in cancer induces secretion of metastasis-promoting cytokines from blood vascular endothelium. Clin Cancer Res 19: 1693-1704, 2013.

31. Van Eckyen E: Breast tumours. In: TNM classification of malignant tumours. 8th edition. Brieley JD, Gospodarowicz MK and Wittekind C (eds). John Wiley and Sons, Ltd., West Sussex, pp151-158, 2017.

32. Faggioli L, Costanzo C, Merola M, Bianchini E, Furia A, Carsana A and Palmieri M: Nuclear factor kappa B (NF-kappa B), nuclear factor interleukin-6 (NFIL-6 or C/EBP beta) and nuclear factor interleukin-6 beta (NFIL6-beta or C/EBP delta) are not sufficient to activate the endogenous interleukin- 6 gene in the human breast carcinoma cell line MCF-7. Comparative analysis with MDA-MB-231 cells, an interleukin-6-expressing human breast carcinoma cell line. Eur J Biochem 239: 624-631, 1996.

33. Robinson EK, Sneige N and Grimm EA: Correlation of interleukin 6 with interleukin 1alpha in human mammary tumours, but not with oestrogen receptor expression. Cytokine 10: 970-976, 1998.

34. Fontanini G, Campani D, Roncella M, Cecchetti D, Calvo S, Toniolo A and Basolo F: Expression of interleukin 6 (IL-6) correlates with oestrogen receptor in human breast carcinoma. Br J Cancer 80: 579-584, 1999.

35. Toi M, Inada K, Suzuki H and Tominaga T: Tumor angiogenesis in breast cancer: Its importance as a prognostic indicator and the association with vascular endothelial growth factor expression. Breast Cancer Res Treat 36: 193-204, 1995.

36. Heer K, Kumar H, Read JR, Fox JN, Monson JR and Kerin MJ: Serum vascular endothelial growth factor in breast cancer: Its relation with cancer type and estrogen receptor status. Clin Cancer Res 7: 3491-3494, 2001.

37. Byrne GJ, McDowell G, Agarawal R, Sinha G, Kumar S and Bundred NJ: Serum vascular endothelial growth factor in breast cancer. Anticancer Res 27 (5B): 3481-3487, 2007.

38. Hodorowicz-Zaniewska D, Kibil W, Małek A, Szpor J, Kulig J and Sztefko K: Evaluation of serum concentrations of vascular endothelial growth factor (VEGF) in breast cancer patients. Pol J Pathol 63: 255-260, 2012.

39. Greenberg S and Rugo HS: Triple-negative breast cancer: Role of antiangiogenic agents. Cancer J 16: 33-38, 2010.

40. Elston CW and Ellis IO: Pathological prognostic factors in breast cancer. I. The value of histological grade in breast cancer: Experience from a large study with long-term follow-up. Histopathology 19: 403-410, 1991.

41. Dossus L, Jimenez-Corona A, Romieu I, Boutron-Ruault MC, Boutten A, Dupré T, Fagherazzi G, Clavel-Chapelon F and Mesrine S: C-reactive protein and postmenopausal breast cancer risk: Results from the E3N cohort study. Cancer Causes Control 25: 533-539, 2014. 